celestial orientations $(a)$ by the fact that they tend to converge, not to diverge, in direction; $(b)$ by the absence of graves at right angles to the prevailing direction.

They may also be orientated by being placed along a road of spirits. There were three main classes of non-orientated burials, those with $(a)$ an absence of any intelligible arrangement whatsoever, as in the British round barrows, (b) a funeral feast arrangement, as among the Siculi and some Amerindians, (c) a "Sociocentric" arrangement, as among the Wotjobaluk, Omaha, Ponka, etc.

In conclusion, Prof. Rose suggested that if his deductions were sound, they afforded, inter alia, a new test of race.

In the discussion which followed the reading of the paper Dr. Rivers, the president, pointed out that Prof. Rose, in coupling reincarnation and terrestrial orientation, had suggested an entirely new con- nection. In Melanesia orientation was usually terrestrial. There was, however, a form of orientation which, while being celestial, had no connection with the cardinal points. It was in the direction of a home of the dead in the sky, which he connected with the Melanesian variant of upright burial and the custom of burying the dead in the sea with weights attached to their legs. Dr. Rivers suggested, further, that our own practice of laying the corpse on its back may be connected with the home of the dead in the sky. Prof. Elliot Smith referred to the custom of the protodynastic Egyptians who buried their dead with the head to the south, while in the second and third dynasties they were buried with the head to the north, in each case towards the country of origin. $\mathrm{Mr} . \mathrm{H}$. Peake pointed out that the terrestrial orientation would tend to become celestial as a people in the course of its wanderings lost the memory of the direction of its original point of departure.

\title{
The National Academy of Sciences, U.S.A.
}

THE annual meeting of the National Academy of Sciences was held at the Smithsonian Institution on April $25-27$. Unusual interest was taken in the meetings owing to the presence of his Serene Highness Albert I., Prince of Monaco, Prof, and Mrs. Albert Einstein, and Dr. Frank Adams, of Montreal, a foreign associate. In accordance with a precedent of long standing, President Harding received the academy.

On Monday evening, April 25, the Prince of Monaco gave an address, illustrated by moving pictures, on his researches in oceanography, for which the Agassiz medal, founded by the late Sir John Murray, was awarded to him by the academy in 19I8. After the address the Prince graciously received the members of the audience at a reception held in the National Gallery of Art.

On Tuesday the president, Dr. C. D. Walcott, extended a welcome to Prof. Albert Einstein on behalf of the academy, to which Prof. Einstein briefly responded, expressing his sense of pleasure at being present at the meeting of the academy and receiving its welcome.

On Tuesday evening, at the annual banquet, the presentation of the academy's medals was made. The Mary Clark Thompson medal, for eminence in researches in palæontology and geology, was awarded for the first time to Dr. Walcott for his classic studies in Cambrian palæontology. The Agassiz medal for Jo1 8 was presented to the Prince of Monaco. The Agassiz medal for I92I was presented to Admiral Sigsbee for his investigations, including deep-sea soundings and other oceanographic work, mainly in the Gulf of Mexico. The Henry Draper gold medal, for eminence in astronomical physics, was awarded to Prof. P. Zeeman, of Amsterdam, for his discovery of the socalled "Zeeman effect" and for the study of the influence of magnetism upon light. In Prof. Zeeman's absence the medal was communicated through Dr. Hubrecht, secretary of the Netherlands Legation. The Daniel Giraud Elliot medal was awarded to Dr. Robert Ridgway for his studies of the birds of North America, especially part viii. of his "Birds of North and Middle America," which has recently appeared. The Hartley gold medal for eminence in the application of science to the public welfare was awarded to Dr. C. W. Stiles for his work in the investigation and eradication of the hookworm disease in the United States.

At the business meeting on Wednesday, April 27,

Dr. Walcott tendered his resignation as president of the academy on account of, his desire to lay down No. 2695 , VOL. IO7] something of the burden of administrative work which he has long carried, and in order to be able to devote himself more completely to his studies of palaontology, but at the unanimous desire of the academy he consented to withdraw his resignation for the remaining two years of his term. Dr. George E. Hale resigned the office of foreign secretary on account of ill-health, and Dr. R. A. Millikan was elected to succeed him. Messrs. Hale and Pearl were elected to the council, and the following new members were elected to the academy: Messrs. Frank Michler Chapman, William Leroy Emmet, William Draper Harkins, Ales Hrdlicka, Arthur Edwin Kennelly, William George MacCallum, Dayton Clarence Miller George Abram Miller, Benjamin Lincoln Robinson, Vesto Melvin Slipher, Lewis Buckley Stillwell, Donald Dexter Van Slyke, Thomas Wayland Vaughan, Henry Stephens Washington, and Robert Sessions Woodworth.

Numerous papers were presented at the scientific sessions. The principal feature was the address of Dr. W. S. Adams, of Mount Wilson Solar Observatory, on his spectrum researches on the motions in the line of sight and the absolute magnitudes of nearly 2000 stars. Dr. Adams pointed out the excellent confirmation of Russell's theory of giant and dwarf stars, and discussed the bearing of the observations on the dependence of stellar velocities upon spectral type and absolute magnitude. He also treated several other questions which are no longer insoluble now that, for the first time, the positions, directions, and velocities in space of such a large and homogeneous mass of stars have become known.

Dr. C. D. Walcott gave a profusely illustrated paper in which he directed attention to the great detail in the structure of the trilobite which he has found by the application of a new photographic process.

Dr. H. F. Osborn, of the American Museum of Natural History, New York, traced the evolution and geographical distribution of the Proboscidea. The two main groups of the mastodons and true elephants were followed, by the aid of skeletal photographs, restorations, and maps, from their original homes in northern Africa and Central Asia in the Eoceñe through their migrations over Europe and Asia to North and South America by way of Bering Strait.

Another paper of the same general character was given by Dr. J. C. Merriam, president of the Carnegie Institution, on his twenty vears of study of the evolution and geographical distribution of the bear family.

Dr. L. R. Jones, of the University of Wisconsin, showed the pathological influence of temperature, and 
the relation of it to the adaptability of certain soils and climates to the growth of the principal food crops.

Dr. Simon Flexner communicated the results of experimental epidemics produced in colonies of mice, in which it was shown that the mortality is enhanced by the introduction of fresh subjects after the epidemic has nearly run its course, the recurrence among the original colony seeming to be promoted by the disease of the new individuals.

Novel experiments on the skin temperature of pachyderms, reported by Dr. F. G. Benedict, embraced measurements of the temperatures of the elephant, rhinoceros, and hippopotamus at the New York Zoological Gardens. The difference between the results for these hairless animals and the results for man seem to depend largely on the great thickness of the skin, with accompanying control by outside as contrasted with interior temperature conditions.

A short popular account was given by Dr. C. G. Abbot of his experiments with solar cooking apparatus on Mount Wilson. The application of the solar heat is indirect through an oil circulatory apparatus, including a reservoir in which are inserted the ovens. All kinds of domestic cooking, except frying, and the preserving of fruits and vegetables were carried on. A jar of preserved pears prepared in the solar cooker was exhibited.

In a paper by J. R. Carson and J. J. Gilbert on transmission characteristics of the submarine cable, further employment was made of the extraordinary opportunity enjoyed by physicists during the war owing to the Government control of the Alaskan cable. A valuable paper had been given on the characteristics of this cable by signal corps officers at the academy meeting of 1920. Further applications of the results were now given.

\section{A New Treatment of Sleeping Sickness.}

$A \mathrm{~T}$ a meeting of the Royal Society of Tropical A. Medicine and Hygiene held on May 2o, Dr. Claude H. Marshall, senior medical officer of the Uganda Protectorate, read a paper on a new treatment of trypanosomiasis (sleeping sickness) which had been originated by Dr. S. M. Vassallo, of the Uganda Medical Service, and himself. Remedies injected into the circulation, though they may sterilise the blood, probably do not destroy the parasites in the central nervous system, since the trypanosomes produce thickening and occlusion of the choroid plexus at an early stage of the disease, and thus prevent the passage of drugs from the circulation into the spinal fluid. In I9I8, therefore, in a well-marked case of sleeping sickness, an intravenous injection of neokharsivan was made, and three hours afterwards $2 \mathrm{oz}$. of the patient's blood was withdrawn; 20 minims of the serum was then injected into the spinal canal, and no further treatment was given; twentyseven months afterwards the patient was quite well, and his blood free from parasites. Of thirty cases similarly treated a large majority were quite well at periods varying from six and a half to twentyseven months afterwards. The results are supposed to be due only in part to the drug contained in the serum; it is held that an antibody, trypanolysin, is formed in the blood of an infected patient, but that this cannot in ordinary circumstances reach the parasites in the central nervous system. Acting on this view, Dr. Vassallo is now treating cases along similar lines, but without previous intravenous injection of the drug. Later speakers emphasised the value of the work of Dr. Marshall and his colleague; but it was pointed out that it was early as yet to claim that the cases were permanently cured.

NO. 2695 , VOL. IO7 7

\section{University and Educational Intelligence.}

CAMBridge. - The Frank Smart prizes for botany and zoology have been awarded to A. J. Smith, Downing College, and G. S. Carter, Gonville and Caius College, respectively.

Glasgow.-Sir John H. Biles has intimated his intention to retire in September next from the John Elder chair of naval architecture and marine engineering, which he has held since r891. Prof. Biles has served in many capacities under the Admiralty and the Board of Trade, and is Consulting Naval Architect to the India Office. He received the thanks of the India Council for his services in designing and constructing river craft for the Mesopotamia Expeditionary Force during the war.

The late Mr. William J. Chrystal, chemical manufacturer, of Shawfield Works, Rutherglen, has bequeathed $10,000 l$. to the University, to be applied as the Senate may determine; and also ro,oool. to the Roval Technical College, for endowment.

Oxford.-Dr. E. Mallam, of Magdalen College, has been appointed Litchfield lecturer in medicine for two years as from October 5 next.

Final approval has been given in Convocation to the statute constituting the Delegacy for the Society of Oxford Home Students, and to the decree authorising the loan of $19,000 l$. from the special reserve fund for the completion of the Dyson Perrins Laboratory.

St. Andrews.-Dr. R. Robinson, director of research in the British Dyestuffs Corporation, Huddersfield, has been appointed professor of chemistry and director of the chemical research laboratory in succession to Prof. Irvine, now Principal of the University.

THE award of the William Gibson research scholarship for medical women (the second since its foundation) has been made by the council of the Royal Society of Medicine to Miss Gertrude M. A. Herzfeld, of Edinburgh.

THE Chemical Age for June is announces that Mr. K. C. Browning, who for many years was Government analyst in Ceylon, has been appointed professor of chemistry and metallurgy at the Artillery College (formerly the Royal Ordnance College), Woolwich.

AT the meeting of Leeds University Court, held on

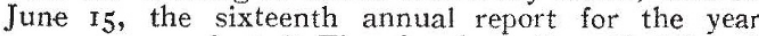
19 I9-20 was adopted. The vice-chancellor, Sir Michael Sadler, addressed the court, and stated that the most urgent question before the university was one of finance. The cost of maintenance was almost double that of 1918 , and the balance sheet for the current year would show a deficit of $14,000 l$. The present income was about $140,000 l$, of which 32.7 per cent. came from Government grants, 16.4 per cent. from local education authorities, 14.8 per cent. from endowments, etc., and $36 \cdot 1$ per cent. from students' fees. At present the average cost per student is $75 l$. per annum, and the average fee paid is $27 l$. It has therefore been decided to adjust the fees to meet the difference between the total cost of the education provided and the funds derived from all other sources. Under present conditions this means an increase of rol. per annum in the tuition fees and a small increase in examination fees. The report contains some account of the work in hand in the various departments, and concludes with a list of donations, etc., from which it appears that during the past year the university has received more than half a million sterling in donations, including eight gifts of ro,oool. and over, and one of $77,250 l .$, in addition to their annual subscription of $4000 l$. from the Clothworkers' Company of London. 